\title{
Med postsocializmom in protosocializmom
}

Ključne besede: Slovenija, tranzicija, kriza, kapitalizem, socializem

\section{Neoliberalne in keynesovske razlage krize}

Konec decembra 2012 smo lahko na naslovnici Reporterja prebrali: »Slovenija mora privatizirati banke ali pa je na poti na Balkan«. Če kot »Balkan« razumemo ostale postjugoslovanske države, je ta izjava v očitnem nasprotju $\mathrm{z}$ dejstvi. Po raziskavi skupine Research on Money and Finance je delež zasebnih bank v celotnem bančnem sistemu na Hrvaškem in v BiH večji od 90 odstotkov, v Srbiji pa večji od 80 odstotkov (Ćetković, 2011). Čeprav je ta izjava očitno empirično lažna, kljub temu vsebuje neko resnico resnico specifičnega ideološkega projekta, ki je spremljal in upravičeval spremembe $\mathrm{v}$ lastniški strukturi in organizaciji postsocialističnih gospodarstev. V tej ideologiji je »Balkan« oznaka za vse, kar odstopa od idealnega modela čistega kapitalizma.

Kulturna in intelektualna zaostalost, kolektivizem ter sovraštvo do individualizma in izvirnosti, nagnjenost $\mathrm{h}$ korupciji, lenoba in nesposobnost, nerazumnost in prevlada nizkih strasti - vse to ta, v zadnjih dveh desetletjih v nedogled ponavljana ideologija predstavlja kot ovire na poti do čistega kapitalizma, definiranega kot kombinacija tržne meritokracije (kjer boljši kadri napredujejo zaradi svojih kompetenc in ne političnih ali sorodstvenih povezav) in konkurenčnosti, ki jo lahko zagotavlja le profitni motiv, očiščen patologij državnega lastništva in intervencij. A takoj naletimo na težavo kako je mogoče, da je bila Slovenija še nedavno najuspešnejši »tranzicijski model", čeprav je privatizirala manj bank in industrije ter obdržala večji javni sektor in višjo raven socialnih pravic kakor druge postjugoslovanske države?

Uradne ekonomske teorije uspešnost tranzicije merijo $\mathrm{z}$ napredovanjem fleksibilizacije trga delovne sile, privatizacije gospodarstva in liberalizacije finančnega trga. To troje bi moralo avtomatsko pripeljati do splošne blaginje, polne zaposlenosti in gospodarske rasti. Slovenija po tem zaostaja za drugimi državami nekdanje Jugoslavije, hkrati pa je pred njimi po stopnji socialne varnosti in zaposlenosti ter po višini osebnih dohodkov. Po drugi strani so Hrvaška, $\mathrm{BiH}$ in Srbija veliko več privatizirale, njihovi trgi delovne sile so fleksibilnejši, davki nižji in socialna država vitkejša, a to ni pripeljalo ne do gospodarske rasti ne do splošne blaginje. 
$\mathrm{Na}$ podlagi teh osnovnih empiričnih dejstev bi lahko pritrdili keynesovskim ekonomistom, kiv nasprotju s predstavniki neoklasičnega ekonomskega »mainstreama« trdijo, da gre relativno uspešnost »slovenskega modela« pripisati prav državnemu lastništvu nad strateško pomembnimi industrijami in večino finančnega sektorja, velikemu javnemu sektorju in razmeroma razviti socialni državi. Gre za klasično polemiko med neoliberalci in keynesovci o pravem načinu doseganja gospodarske uspešnosti (če to merimo z obsegom zaposlenosti in stopnjo gospodarske rasti). Prvi trdijo, da je pravi način zmanjševanje obsega socialnih transferjev, ki naj bi prebivalstvo spodbudilo $\mathrm{k}$ delu, in povečanje učinkovitosti javnih storitev $\mathrm{z}$ njihovo privatizacijo. Polno zaposlenost želijo doseči s fleksibilizacijo trga delovne sile, ekonomsko aktivnost pa spodbuditi z zniževanjem davkov. Drugi trdijo obratno: namesto ponudbe poudarjajo povpraševanje, kar pomeni visoke plače in socialne transferje, ter pomen močnega javnega sektorja, ki zagotavlja stabilno družbeno infrastrukturo (denimo telekomunikacije in transport) ter produktivnost delovne sile (šolstvo, zdravstvo). A oboji se strinjajo, da je kapitalizem optimalen družbenoekonomski sistem. Njihovi pogledi se razlikujejo le glede na to, po kateri poti kapitalizem deluje čim učinkoviteje in razvije vse svoje potenciale.

Desetletje relativne uspešnosti Slovenije (od poznih devetdesetih let do začetka sedanje krize) na prvi pogled empirično potrjuje keynesovsko teorijo. A prav v času krize so se tako teoretsko kakor politično okrepili neoliberalni glasovi. V zadnjih nekaj letih se je klasični balkanistični argumentaciji za neoliberalne reforme pridružila še tehnokratska. Po tej novi različici neoliberalne »teorije« je lahko keynesovska ekonomska politika kratkoročno uspešna, a bo srednjeročno zaradi zapravljivosti države in delavske nediscipline privedla do ekonomskega (in s tem socialnega) zloma in krize. Dolgoročno, menijo neoliberalci, se je mogoče izviti iz krize in postaviti temelje stabilnega in vzdržnega razvoja le na način fiskalne konsolidacije, novih privatizacij ter »strukturnih reform « trga delovne sile, pokojninskega sistema in davčne politike. Desetletje relativne blaginje je bilo po tej teoriji nevzdržno - treba je postaviti nove, neoliberalne temelje za prihodnjo blaginjo, s čimer se strinjata tudi Evropska komisija in OECD, ki v svojih letnih enciklikah Slovenije ne pozabita opomniti, da ima glede privatizacij in liberalizacij še ogromno manevrskega prostora.

A lahko se vprašamo, zakaj tedaj vzpostavljanje neoliberalnih temeljev za stabilen razvoj in občo blaginjo na način šokterapije, hitre razprodaje državnega premoženja, liberalizacije finančnih sektorjev in fleksibilizacije trgov delovne sile ni učinkovalo $\mathrm{v}$ drugih postjugoslovanskih državah. Odgovor neoliberalcev bi verjetno vključeval ponovno poseganje po balkanističnih argumentih - načelno gre za pravo pot, a tu ni bila uspešna zaradi pohlepnosti lokalnih plemenskih poglavarjev, pomanjkanja podjetniškega duha med njihovimi podaniki, ki so preveč odvisni od države, 
zakoreninjene korupcije in klientelizma. Poleg ekonomske bi bila nujna še kulturna revolucija in prva je spodletela zaradi odsotnosti druge.

Ta ideološki premik na teren moralne filozofije je potreben, da bi ekonomski argumenti za neoliberalizem ostali nedotaknjeni in da bi se keynesovski model izkazal za utelešenje kulturne in intelektualne zaostalosti »Balkana«. Vse kulturne patologije Balkana tako najdejo ustrezne institucije $\mathrm{v}$ "pajdaškem kapitalizmu« $\mathrm{z}$ velikim javnim sektorjem, javno upravo, $v$ kateri se redijo nesposobni, a politično dobro povezani kadri, državnim nadzorom nad ekonomijo, ki ščiti lokalne »botre«, ki se bojijo tuje konkurence ... Balkanistično-neoliberalna ideologija, ki je bila na prelomu tisočletja v Sloveniji precej odtujena od ekonomske in socialne realnosti, v krizi uzre priložnost za moralni preporod. V procesu evropskih integracij, ki se je končal $\mathrm{z}$ vstopom v EU in prevzemom evra, je Slovenija morda pridobila dovolj »evropskih vrednot«, da bi uvedba ostrih neoliberalnih ekonomskih in socialnih politik lahko uspela, če le opustimo gradualistični model razvoja. Tako akademski kakor politični del slovenskega neoliberalnega »establishmenta "zahteva strukturne reforme ne le ekonomije, sociale in trga delovne sile, temveč tudi šolstva, medijev in kulture, kar bi omogočilo vzpostavljanje tistega, kar profesor Borut Rončević (2011) imenuje "politična tehnologija za drugo republiko«.

Kljub vsem razlikam poleg konsenza, da je kapitalizem najboljši ali vsaj najmanj slab družbenoekonomski sistem, keynesovce in neoliberalce druži še nekaj: nimajo endogene teorije krize. Za oboje krize $\mathrm{v}$ kapitalizmu niso rezultat njegove notranje dinamike, temveč zunanjih dejavnikov, kakršni so državne intervencije in dušenje svobodne podjetniške pobude ali neoptimalna državna regulacija, ki še ni dorasla »živalskim duhovom« kapitalizma. Ko bi bil neoliberalni ali keynesovski model v celoti vzpostavljen, bi tudi krize izginile. Tudi ciklični upad v poslovnem ciklu bi lahko hitro sanirali bodisi s stimulacijo agregatnega povpraševanja, velikimi državnimi investicijami in ekspanzivno fiskalno politiko bodisi s spodbujanjem ekonomske aktivnosti na način zniževanja davkov ter privatizacijami in varčevalnimi ukrepi. A če obrnemo perspektivo in upoštevamo tretjo, nekoč prevladujočo, danes pa obrobno marksistično ekonomsko teorijo, po kateri so krize kapitalizmu endogene in izhajajo iz njegove protislovnosti, se pokaže, da so tako neoliberalne kakor keynesovske teorije delno pravilne, a hkrati nezadostne, saj nimajo ustrezne teorije krize.

\section{Razredna in krizna dinamika evropskega kapitalizma}

V nasprotju s tako ortodoksno kakor heterodoksno (keynesovsko) ekonomiko marksistična ekonomska teorija krize obravnava kot kapitalizmu endogene in kot nujne, vse dokler je kapitalizem prevladujoči produkcijski način. Zakaj? Eden izmed 
razlogov je tendenca $\mathrm{k}$ padanju profitne stopnje, ki jo povzroča rast organske sestave kapitala. Da bi bili konkurenčni, tako posamezna podjetja kakor kapitalistična industrija kot celota težijo $\mathrm{k}$ povečanju produktivnosti. Ker so možnosti večanja produktivnosti na način intenziviranja delovnega procesa in pritiska na delavce omejene, rast produktivnosti večinoma zagotavljajo uvajanje novih strojev, tehnološke inovacije in avtomatizacija proizvodnje (kar velja tako za klasične industrijske kakor za storitvene dejavnosti). Avtomatizacija ima za kapitaliste še to dodatno prednost, da delovno silo, s tem ko jo dekvalificira, tudi disciplinira.

Avtomatizacija ne poveča vrednosti izdelkov - ta v totalu produkcije ni odvisna od produktivnosti oziroma hitrosti produkcije, temveč od deleža živega dela $\mathrm{v}$ produkcijskem procesu, kar pomeni, da se $z$ večanjem produktivnosti na način tehnoloških inovacij vrednost posameznih izdelkov celo zmanjšuje, saj enak vnos živega dela (oziroma variabilnega kapitala) proizvede več izdelkov v enaki časovni enoti. A kljub temu skok v produktivnosti posamezni produkcijski enoti začasno (dokler se njena inovacija, s katero je dosegla svojo konkurenčno prednost, ne razširi po celotnem sektorju) omogoča realizacijo ekstraprofitov, saj lahko svoje izdelke prodaja po enaki ceni kakor nižje produktivna konkurenčna podjetja (se pravi po ceni, ki je višja od vrednosti izdelkov) in jih lahko proda več, saj jih proizvaja hitreje. Sčasoma se vsaka uspešna tehnološka inovacija splošno razširi in dvigne splošno raven produktivnosti, kar podjetja sili v iskanje vedno novih inovacij, ki bi jim prinesle začasno konkurenčno prednost.

Temna plat te konkurenčne logike je rast organske sestave kapitala. Ta je definirana kot razmerje med deležem konstantnega (stroji oziroma industrijska tehnologija) in variabilnega kapitala (živo delo). Ker delež variabilnega kapitala z napredkom avtomatizacije pada, hkrati pada tudi totalni obseg vrednosti in s tem presežne vrednosti. Profitna stopnja, definirana kot stopnja eksploatacije (presežna vrednost, ulomljena $\mathrm{z}$ vrednostjo variabilnega kapitala), ulomljena $\mathrm{z}$ organsko sestavo kapitala +1 , z naraščanjem organske sestave kapitala pada. Ko upade do stopnje, ki ogroža profitabilnost novih investicij, kapitalisti »stavkajo« ali pa namesto v produktivne sektorje investirajo v vrednostne papirje. Rezultat je dvojna kriza: po eni strani finančna kriza zaradi hipertrofije finančnih dejavnosti brez ustrezne vrednostne podlage, po drugi strani pa investicijski krč, rast nezaposlenosti, nizka ali negativna gospodarska rast in prezadolženost.

Tendenca k padanju profitne stopnje ni absolutna, obstajajo številne protitendence. Ena izmed njih je povišanje stopnje eksploatacije na način pritiska na individualne ali družbene mezde (denarni socialni transferji in brezplačne javne storitve). Druga je iskanje novih trgov oziroma trgovinska širitev. Tretja je padanje vrednosti konstantnega 
kapitala, ki je kakor rast organske sestave kapitala posledica uvajanja novih industrijskih tehnologij in avtomatizacije, ki zmanjšujeta vrednost tako potrošnih kakor kapitalskih dobrin. Četrta je širitev industrijskih modelov produkcije na področja, na katerih je prej prevladovala nizka organska sestava kapitala. A v zgodovinskih okoliščinah, v katerih tendenca padanja profitne stopnje prevlada nad protitendencami, to pripelje do ugodnih razmer za krizo.

Funkcija krize v kapitalizmu je $\mathrm{v}$ tem, da sistem očisti neproduktivnih in nekonkurenčnih kapitalov ter zniža mezde in socialne pravice, s tem pa ustvari ugodne okoliščine za ekonomsko okrevanje. Okrevanje je odvisno predvsem od potencialne profitabilnosti novih investicij: če je ta dovolj visoka, bodo kapitalisti ponovno začeli investirati in s tem zagnali nov poslovni cikel. V recesiji so propadla podjetja naprodaj za smešno nizke cene, osiromašeni delavci pristajajo na nižje mezde in manjši obseg socialnih pravic, brezposelni od zunaj pritiskajo na zaposlene, panične vlade pa znižujejo davke in rešujejo banke $z$ davkoplačevalskim denarjem. Osnovni pogoj okrevanja profitabilnosti investicij je obsežno uničenje tako proizvodnih zmogljivosti kakor življenjskega standarda prebivalstva, kar pogosto spremlja tudi omejevanje demokracije, potrebno za nemoteno izvajanje "nujnih" varčevalnih ukrepov, množičnih odpuščanj in zmanjševanja socialnih pravic (McNally, 2012).

V ekonomskem razvoju EU od devetdesetih let do prenosa krize v Evropo v letih 2008-2009 lahko opazimo delovanje treh pomembnih protitendenc glede na padanje profitne stopnje. Institucionalna »arhitektura « EU, kjer je monetarna politika rigidna in centralno planirana s strani Evropske centralne banke ter se mora fiskalna politika uklanjati maastrichtskim pravilom, države članice sili v socialni »dumping«, saj je pritisk na delavske in socialne pravice $v$ takšnih razmerah edino sredstvo prilagajanja na konkurenčne pritiske znotraj skupnega trga. To vodi v koordinirano zniževanje mezd in delavskih pravic, ki se v uradnih dokumentih EU imenuje fleksibilizacija trgov delovne sile (Bonefeld, 2002). S tovrstnim povečevanjem stopnje eksploatacije je že v devetdesetih letih začela ekonomsko najmočnejša država EU Nemčija. S tem je izvajala konkurenčni pritisk na ostale države članice, ki so poskušale in še poskušajo na vsak način znižati stroške dela in omejiti izdatke za javne storitve (Lapavitsas in drugi, 2012). A izhodiščni položaj središčnih držav evroobmočja (Nemčija, Avstrija, države Beneluksa, Švedska) je veliko boljši, saj so imele na začetku procesa neoliberalnih evrointegracij razvitejše socialne institucije in s tem več manevrskega prostora, medtem ko ima zmanjševanje obsega že v izhodišču »vitkejših « socialnih institucij v revnejših državah evropskega obrobja veliko hujše posledice, saj vsak sveženj varčevalnih ukrepov takoj pomeni veliko povečanje revščine in družbene nemire. 
Za center EU je značilna neomerkantilistična ekonomska politika, ki temelji na izvozu (Bellofiore, Garibaldo, Halevi, 2011). Širjenje zunanje trgovine hkrati rešuje problem nizkega domačega povpraševanja, ki ga povzroči pritisk na mezde in ki bi lahko za zasebni sektor predstavljalo realizacijski problem, ter padanja profitne stopnje. Neomerkantilistična strategija ni omejena na materialne izdelke, saj vključuje tudi izvoz kreditov, s čimer so Nemčija in druge države središča EU v tujini spodbujale in hkrati financirale povpraševanje po njihovem izvozu. Obenem je širjenje mednarodne trgovine s krediti povečalo tudi investicijske možnosti za tiste kapitaliste, ki so iskali priložnosti v naložbah v vrednostne papirje.

$\mathrm{V}$ valovih privatizacij, značilnih za evropski ekonomski razvoj od devetdesetih let naprej (Frangakis in drugi (ur.), 2009), lahko vidimo tretjo protitendenco glede na padanje profitne stopnje. Privatizacija šolstva, zdravstva in javnega dela kulture pomeni vključevanje delovnointenzivnih sektorjev $\mathrm{v}$ proces akumulacije kapitala ter priložnost za "racionalizacijo" in "modernizacijo« na način »novega javnega upravljanja« ter uvajanja novih informacijskih in komunikacijskih tehnologij. S privatizacijo javnih storitev se odprejo povsem novi trgi in po novem zasebna podjetja nasledijo razmeroma nizko organsko sestavo kapitala, značilno za delovnointenzivne javne storitve, kar pomeni, da je $\mathrm{z}$ »industrializacijo« mogoče to izhodiščno nizko organsko sestavo kapitala višati in ob tem žeti ekstraprofite.

Te protitendence so od poznih devetdesetih let do uvoza krize v Evropo stabilizirale evropski kapitalizem, a na protisloven način. Stabilnost evropskega kapitalizma je $\mathrm{v}$ tem času temeljila na nizki rasti v središču in kreditni ekspanziji na obrobju, na stagnaciji realnih plač, postopni eroziji socialnih držav, opuščanju »welfare» in uvajanju »workfare« socialnih politik ter koncentraciji tehnološkega »cutting edge» v centru. Prenos krize iz ZDA je razkril dejansko krhkost te navidezne stabilnosti. Zunanja trgovina Nemčije je zaradi svetovnega ekonomskega kolapsa leta 2009 utrpela veliko škodo. Zato je Nemčija pritisnila na sredozemske države, naj plačajo svoje dolgove. Zaradi usahnitve kreditnih tokov se je zrušila na kreditih temelječa rast evropskega obrobja. Na nemško industrijo priključen del evropskega obrobja (med drugim Slovenija) je utrpel posledice industrijskega »downsizinga « v centru. Recesija je središče EU prizadela mnogo manj kakor obrobje, a se zaradi padca kupne moči obrobja kljub temu srečuje s problemom realizacije. Ker politične elite centra niso pripravljene uvesti keynesovskega spodbujanja domačega povpraševanja s fiskalno ekspanzijo in višanjem mezd, je profitabilnost evropskega kapitalizma kot celote danes odvisna od ropanja obrobja, predvsem Grčije. Dolgotrajna stagnacija in poznejši nagli padec življenjskega standarda sta privedla do množičnih demonstracij in uporov, pa tudi do vzpona neofašistične politike. Evropski kapitalizem je v zadnjih letih izgubil svoj človeški obraz, natančneje, svojo človeško masko. 


\section{Kapitalizem »s slovenskimi značilnostmi«}

Aplicirajmo zdaj širši kontekst evropskega kapitalizma ter splošno marksistično teorijo krizne in razredne dinamike kapitalizma na Slovenijo. Ena najbolj problematičnih zgodovinskih dediščin mladega slovenskega kapitalizma devetdesetih let je bila nizka produktivnost industrije. Razloga za nizko produktivnost sta bila dva. Delavci so se v socializmu navadili na ležeren tempo dela, saj so v samoupravljanju svojo družbeno moč uporabljali za nižanje intenzivnosti delovnega procesa, podaljševanje prostega časa in poviševanje osebnih dohodkov. A nizka produktivnost ni, kot trdijo liberalni kritiki, nujen in neizbežen učinek socializma, temveč so $\mathrm{v}$ specifičnih zgodovinskih okoliščinah ločenosti od možnosti vplivanja na splošno družbeno planiranje delavci izbrali nižanje intenzivnosti dela in višanje mezd (Lebowitz, 2006, 73-85). Drugi razlog za nizko produktivnost pa je bila razmeroma nizka tehnološka razvitost Jugoslavije, ki je v poznih sedemdesetih in $\mathrm{v}$ osemdesetih letih izgubila korak $\mathrm{z}$ razvitimi kapitalističnimi državami.

Nizka produktivnost je problematična že v protekcionističnem modelu državno reguliranega kapitalizma, še bolj problematična pa postane $\mathrm{v}$ primeru majhnega, odprtega in izvozno usmerjenega gospodarstva, kakršno je slovensko. $\mathrm{V}$ tem primeru se neposredno prevede $v$ nizko konkurenčnost na mednarodnem trgu. Ker tranzicijske države niso bile deležne ničesar, kar bi bilo podobno Marshallovemu planu ali tehnološkemu prenosu z Zahoda, ki je v osemdesetih letih omogočil vzpon t. i. azijskih tigrov, Slovenija ni mogla posnemati azijskega modela visokotehnološkega izvozno usmerjenega razvoja. Deli industrije so bili tako prepuščeni propadanju, nekateri sektorji pa so se preusmerili v podizvajalsko proizvodnjo nizkotehnoloških izdelkov za tuje trge.

Zagata s tehnologijo $\mathrm{v}$ kapitalizmu ni le $\mathrm{v}$ (potencialnem) zniževanju profitne stopnje, temveč so tehnološke inovacije hkrati nujne za povečevanje relativne presežne vrednosti. Ker povečanje produktivnosti znotraj fiksne dolžine delovnega dne znižuje obseg časa, $v$ katerem delavci delajo za lastno reprodukcijo, in povečuje obseg časa, $v$ katerem delajo za kapitalista, to pomeni tudi povečanje obsega (relativne) presežne vrednosti. Tehnološki razvoj, ki za ekonomijo v totalu pomeni tveganje padanja splošne profitne stopnje, je obenem edini način za povečevanje individualnih profitov oziroma obsega relativne presežne vrednosti. Produktivnost je mogoče do določene mere višati $\mathrm{z}$ reorganizacijo delovnega procesa in discipliniranjem delavcev. Oboje je bilo v Sloveniji v zadnjih dveh desetletjih radikalno, a so rezultati v primerjavi $s$ tehnološko intenzivnim razvojem vedno skromni. Drugi način kompenzacije za nizko tehnološko razvitost je razvoj nizkomezdnih delovnointenzivnih sektorjev, kjer same nizke mezde omogočajo dovolj visoke profite, da avtomatizacija ni nujna ali se sploh ne 
izplača. Nizke mezde se v teh primerih dopolnjujejo z izjemno intenzivnim delovnim ritmom in podaljševanjem delovnega dne oziroma vračanjem na akumulacijo kapitala na način absolutne presežne vrednosti. To je »razvojni model« Bangladeša, Filipinov ali Malezije.

Slovenski kapitalistični razvoj je ubral vse tri poti in tako povzročil izrazito segmentacijo delavskega razreda. Po eni strani je na nekaterih področjih, zlasti $\mathrm{v}$ farmacevtski industriji, visokotehnološki preboj uspel. Rezultat je nekaj uspešnih visokotehnoloških podjetij $\mathrm{z}$ dobro plačanimi delovnimi mesti, ne pa tudi preboj $\mathrm{v}$ splošni stopnji tehnološke razvitosti gospodarstva, ki ostaja razdeljeno na peščico tehnološko visoko razvitih sektorjev in nizko razvito večino. Tehnološki zaostanek je posebej očiten na ključnih področjih: Slovenija nima lastne proizvodnje računalnikov, robotike ali telekomunikacijskih naprav.

Po drugi strani je bil delavski razred v Sloveniji v devetdesetih letih preveč bojevit in predobro sindikalno organiziran, da bi projekt hitre reorganizacije delovnih procesov ali radikalnega znižanja mezd mogel uspeti. Odgovor države in kapitala je bil razvoj paralelnega in izrazito prekariziranega trga delovne sile, $v$ katerega so vključeni mladi ustvarjalci, kulturniki, novinarji, oblikovalci in drugi, ki delajo za nizke honorarje in so slabo socialno podprti. Splošna strategija kapitalističnega razreda v Sloveniji je bila $\mathrm{v}$ tem, da se zaradi odpora sindikatov dopusti razmeroma visoka stopnja sindikalne pokritosti in socialne varnosti stalno zaposlenih, hkrati pa se za te pravice in varnost prikrajša tiste, ki na novo vstopajo na trg delovne sile, zlasti v novih »industrijah«, povezanih z internetom, novimi kulturnimi praksami ipd. Hkrati so tako javne institucije kakor zasebna podjetja $\mathrm{v}$ klasičnih gospodarskih panogah sčasoma začela najemati vse več nesindikaliziranih mladih prekarnih delavcev in delavk. Delež zaposlenih za delni in/ali določen delovni čas se je v Sloveniji med letoma 1997 in 2007 podvojil in je bil leta 2007 med najvišjimi v EU, enako kakor stopnja izgorelosti in stresa, povezana $z$ negotovimi delovnimi pogoji in razmerami (UMAR, 2009, 37). $\mathrm{V}$ času krize se je ta delež zmanjšal, a le zato, ker so tako zasebna podjetja kakor javne institucije zaradi zmanjšanja prometa ali proračunskih rezov najprej odpuščala prav prekarne delavce.

Tretjič, podjetniki so v nekaterih sektorjih industrije, $\mathrm{v}$ nizko plačanih storitvenih dejavnostih (čiščenje, varovanje, maloprodaja itn.) in predvsem v gradbeništvu začeli množično najemati migrantske delavce in delavke, predvsem iz BiH in Srbije. Zaradi manipulacij z vizami in delovnimi dovoljenji, ki jih je omogočil vstop v schengenski režim, je bil ta del delavskega razreda hipereksploatiran, njegovi delovni pogoji in plače pa blizu temni strani t. i. azijskega modela. 
Državna ekonomska in socialna politika Slovenije v obdobju tranzicije je bila $\mathrm{v}$ postopnem in delnem zniževanju davkov na kapital in najvišje osebne dohodke, zmanjševanju obsega socialnih pravic in organizaciji privatizacijskih valov. Vse to je do določene mere omogočalo profitabilnost gospodarstva, a ni moglo povsem kompenzirati odsotnosti visokotehnološkega razvoja, značilnega za razvite kapitalistične države. Medtem ko je bil v drugih postjugoslovanskih državah odgovor vlad na tehnološko zaostalost in s tem mednarodno nekonkurenčnost gospodarstva $\mathrm{v}$ tem, da so dopustile propad industrije, družbene infrastrukture in življenjskega standarda prebivalstva, je bil v Sloveniji odgovor keynesovski: ohraniti čim večji vpliv države v industriji, finančnem sektorju in družbeni infrastrukturi ter čim večji del zasebnega sektorja ohraniti $\mathrm{v}$ rokah etnično avtohtonih menedžerjev (večina privatizacij v Sloveniji je bila internih, medtem ko je bila stopnja neposrednih tujih investicij nizka). To je kljub ne ravno visoki profitabilnosti gospodarstva zagotavljalo razmeroma visoko stopnjo zaposlenosti in gospodarske aktivnosti.

Splošno gledano je Slovenija v dvajsetih letih tranzicije prešla skozi obe fazi kapitalističnega razvoja, značilnega za zahodnoevropsko ekonomijo po drugi svetovni vojni: fazo relativne blaginje in rasti ter fazo neoliberalne kontrarevolucije in permanentne recesije. To pomeni, da t. i. slovenski model še zdaleč ni imun na splošna protislovja kapitalizma in da je lahko njegova »uspešnost « trajala le do prve resne krize. Zaradi neenakega razvoja, značilnega za kapitalizem nasploh, posebej pa za evropski kapitalizem zadnjih dvajsetih let, obrobne države niso nosilci, ampak prejemniki splošne razvojne dinamike. Slovenija ni prav nič sodelovala »v pripravah« na sedanjo krizo - slovenske banke poslujejo konservativno in ne izdajajo »sub-prime« hipotek, tehnološki razvoj pa je bil prešibek, da bi lahko organska sestava kapitala tako narasla, da bi ogrožala profitabilnost investicij. A sama odprtost slovenskega gospodarstva ter priključenost na mednarodne gospodarske in finančne tokove zagotavljata, da krize, ki se običajno začnejo v centru, Slovenije ne bodo obšle.

Toda ali lahko recesija, potem ko uniči dovolj nekonkurenčnih posameznih kapitalov in dovolj zniža stroške dela, privede do novega vzpona in preporoda slovenske zgodbe o uspehu? V to težko verjamemo. Zahteve OECD in Evropske komisije po permanentnih varčevalnih ukrepih so prevelike in brez radikalnih političnih sprememb bo nemogoče ukiniti neoliberalne strukturne reforme, sprejete $\mathrm{v}$ času krize, kar pomeni, da tudi morebitno okrevanje gospodarstva (tako kakor $\mathrm{v}$ ZDA) ne bo imelo pozitivnih učinkov na stopnjo zaposlenosti ali blaginjo prebivalstva. Večja integracija v evropski oziroma svetovni kapitalizem pomeni tudi večji pritisk na delavstvo in socialno državo; in težko je verjeti, da se lahko v primeru vrnitve rasti obnovijo keynesovske ekonomske in socialne politike. Problem Slovenije danes ni premajhna oddaljenost od Balkana, pač pa prevelika bližina Evrope. Po drugi strani 
rešitev ni »odklapljanje« od svetovnih tokov kapitala, saj bi to pomenilo politični in ekonomski samomor (Grahl, 2012a), temveč koordiniran radikalen obrat v levo na evropski ravni (Husson, 2012).

\section{Zakaj kapitalizem ne deluje, tudi ko deluje, in kakšne so alternative}

Boj za socialistično alternativo je danes morda težji in napornejši kakor kadarkoli doslej. Delno je tako zaradi neuspehov in ideološke diskreditiranosti realno obstoječih socializmov, delno pa zato, ker je danes Evropa združena na podlagi izrazito antisocialističnih načel in institucij (če zanemarimo nekatera zgolj retorična sklicevanja na »evropski socialni model«: Grahl, 2012b), ki so brez demokratičnega nadzora (Baker, 2011). Keynesovsko-socialdemokratske alternative neoliberalnemu kapitalizmu so zaradi nedostopnosti radikalnejših socialističnih alternativ videti privlačne in realistične. Razvita socialna država, državne investicije $\mathrm{v}$ prioritetne razvojne panoge, vzpostavljanje polne zaposlenosti in dvig minimalne plače so gotovo pomembni politični cilji, ki si zaslužijo vso podporo, a ne odpravljajo nagnjenosti kapitalizma h krizam, ki ponavadi uničujejo prav dosežke socialdemokratskih bojev $\mathrm{v}$ kapitalizmu. Poleg tega zaostreni pogoji mednarodne konkurence onemogočajo »keynesovstvo v eni deželi«.

A naredimo miselni eksperiment in predpostavimo, da je keynesovski kapitalizem $\mathrm{v}$ eni deželi mogoč in da lahko državna regulacija, discipliniranje kapitala in vzdrževanje visoke ravni efektivnega povpraševanja preprečijo ali vsaj ublažijo krize in pospešijo okrevanje. Osnovni marksistični argument za to, da se je za socializem (in ne le za pravičnejši kapitalizem) vredno boriti tudi v neugodnih okoliščinah, je odvisen od uspešnosti kritike kapitalizma, tudi ko ta deluje, tj. v (hipotetični) situaciji polne zaposlenosti, visokih plač, progresivne davčne politike in razvite socialne države. Pri tem moramo upoštevati, da boj za socializem še zdaleč ne izključuje hkratnega boja za socializacijo kapitalizma. Nasprotno, boj za socializacijo pomeni razvijanje prav tistih institucij, ki so po Marxu zametki prihodnje družbe v sedanji, le da v socialistični perspektivi v nasprotju s socialdemokratsko socializacija kapitalizma ni končni cilj, ampak šele začetno izhodišče dolgoročnejšega boja.

Pri kritiki kapitalizma celo tedaj, ko deluje, je najpomembnejše to, da še tako socializiran kapitalizem ohranja razredno delitev družbe in strukturno podrejenost enega razreda drugemu. Ne glede na stopnjo zaposlenosti ali razvitosti socialne države je delavski razred v kapitalizmu podvržen eksploataciji, delo pa je realno subsumirano pod kapital. 
Prvo pomeni, da delavci nimajo možnosti upravljanja s presežno vrednostjo, ustvarjeno v produkcijskem procesu. Četudi so davki progresivni in visoki ter je večina državnega proračuna namenjena socialnim storitvam, je ta način družbene redistribucije odtujen, saj z redistribucijo ne upravljajo množice same, temveč od množic ločene državne institucije. Te družbenih potreb, ki naj bi jih zadovoljevale, ne spoznavajo neposredno, $\mathrm{z}$ demokratično participacijo množic, ampak posredno, z objektivacijo delavskega razreda na način državnih statistik in birokratskega nadzora. Za začetek poti v socializem niso dovolj le ekonomski ukrepi, kakršna sta povišanje davka na dobiček ali strožja regulacija finančnega sektorja, temveč tudi demokratizacija, debirokratizacija in socializacija institucij, namenjenih družbeni reprodukciji, in njihovo približanje realnim človeškim potrebam in ne njihovim statističnim približkom. Enako velja za ekonomsko planiranje. Medtem ko keynesovci verjamejo v racionalnost kapitalistov, ki naj bi jih bilo treba le malce usmerjati $\mathrm{z}$ državnimi subvencijami, davčnimi spodbudami in spreminjanjem obrestne mere, je osnovna socialistična zahteva socializacija investicijske politike in demokratično odločanje delavcev o tem, kam in kako se bo investiralo ter kakšni deleži presežne vrednosti bodo namenjeni družbeni reprodukciji, povišanju plač in novim investicijam. Skratka, gre za demokratično delavsko samoupravljanje. Takšna koncepcija delavskega samoupravljanja seveda ne rešuje vprašanja zunanjega konkurenčnega pritiska, ki delavce, četudi so lastniki in/ali upravljavci posameznih podjetij, sili, da se obnašajo kot svoji lastni kapitalisti, tj. da disciplinirajo in eksploatirajo same sebe. Enako pomembno vprašanje, ki pa ga tokrat puščamo ob strani, je vprašanje ustrezne izobrazbe delavcev. Kot je pokazala zgodovinska izkušnja socialističnega samoupravljanja, namreč delavci, če nimajo ustrezne izobrazbe za vodenje investicijske politike, težijo le k maksimizaciji svojih osebnih dohodkov, kar lahko ovira splošni družbeni razvoj (Lebowitz, 2010).

Kar pa zadeva realno subsumpcijo, delavci, četudi je ta ali ona zgodovinska različica kapitalizma sposobna zagotoviti polno zaposlenost ali visok standard osebne potrošnje, niso nič manj ločeni od možnosti vplivanja na to, kako je organiziran delovni proces, kakšni stroji se pri tem uporabljajo in kako se distribuirajo izdelki. Socialistična politika se ne more zadovoljiti z organizacijo družbene proizvodnje, $\mathrm{v}$ kateri so delavci strukturno deformirani, reducirani na privesek strojev, ločeni od svojih polnih kreativnih in produktivnih potencialov ter prepuščeni družbeni delitvi dela, ki jih ločuje tako od drugih producentov kakor od potrošnikov njihovih izdelkov.

Ker niti popolna socializacija kapitalizma ne odpravlja eksploatacije in realne subsumpcije, lahko ugotovimo, da kapitalizem ne deluje niti takrat, kadar deluje, in da ga moramo, čeprav je kratkoročno nujno, da njegovo neoliberalno različico 
socializiramo, dolgoročno odpraviti ter zamenjati s humanejšo in pravičnejšo obliko organizacije družbene produkcije in reprodukcije.

Vprašanja alternativ kapitalizmu, boja proti njemu in organizacije družbenega življenja po njem niso akademska, ampak usodna politična vprašanja sedanjosti. Analitična in strateška nezadostnost socialdemokratskih »alternativ« kaže, da je teoretsko in politično najbolj smiselne alternative kapitalizmu še vedno mogoče najti v polju marksistične teorije in socialistične politike. Prevladujoča ideologija zadnjih dveh desetletij je trdila, da privatizacije, strukturne reforme in ukinjanje socialnih pravic nimajo alternative. Danes je očitno, da kapitalizem sam ni opcija, da je zgodovinsko izčrpan ter da ne more zagotavljati družbenega razvoja in napredka. Morda je izbruh množičnih vstaj po vsej Evropi znak, da smo iz postsocializma prešli v protosocializem.

\section{Literatura}

Baker, D., Tiranija Evropske centralne banke, Slobodni filozofski, 2011, http:// www.slobodnifilozofski.com/2011/05/dean-baker-strahovlada-ecb.html [20. 2. 2013].

Bellofiore, R., Garibaldo, F., Halevi, J., The Global Crisis and the Crisis of European Neomercantilism, Socialist Register 47, 2011, str. 120-146.

Bonefeld, W., Class and EMU, The Commoner5, 2002, http://www.commoner.org.uk/ index.php? $\mathrm{p}=9$ [20. 2. 2013].

Ćetković, P., Credit Growth and Instability in Balkan Countries: The Role of Foreign Banks, Research on Money and Finance, Discussion Paper 27, 2011, http:// researchonmoneyandfinance.org/media/papers/RMF-27-Cetkovic.pdf [20. 2. 2013].

Frangakis, M. in drugi (ur.), Privatization against the European Social Model, Houndmills 2009.

Grahl, J., North Korea by the Acropolis, Workers' Liberty, 2012a, http://www. workersliberty.org/story/2012/11/07/north-korea-acropolis [20. 2. 2013].

Grahl, J., The End of Social Europe? State of Nature, 2012b, http://www.stateofnature. org/theEndOfSocialEurope.html [20. 2. 2013].

Husson, M., Čisti kapitalizem, Ljubljana 2012.

Lapavitsas, C. in drugi, Crisis in the Eurozone, London 2012.

Lebowitz, M., Build it Now, New York 2006.

Lebowitz, M., The Socialist Alternative, New York 2010.

McNally, D., The Continuing Global Slump, 2012, http://davidmcnally.org/?p=545 [20. 2. 2013]. 
Rončević, B., Politična tehnologija za drugo republiko, 2011, http://brmagazin.blog. com/2011/09/25/politicna-tehnologija-za-drugo-republiko/ [20. 2. 2013].

UMAR, Poročilo o razvoju 2009, 2009, http://www.umar.gov.si/fileadmin/user_upload/ publikacije/pr/2009/por2009.pdf\#17 [20. 2. 2013]. 


\section{Primož Krašovec}

\section{Between post-socialism and proto-socialism}

Keywords: Slovenia, transition, crisis, capitalism, socialism

The difference in transitional development and success between Slovenia and other post-Yugoslav countries seems to suggest that the basic post-socialist ideology, which connects economic and social hardships to the remains of "Balkan mentality" and excessive state control over the economy, is in contradiction with the facts. Among these countries, Slovenia was the one that was the first to enter the European Union and that was economically and socially the most successful during the transition, while retaining state control over its banks, social infrastructure and part of industry.

On the other hand, the ongoing crisis has seriously endangered the state and the prospects of the Slovenian "success story." With the recession entering into its fourth year, the question arises whether small peripheral European countries can recover within the existing political and economic frameworks, or whether perhaps the time for more radical alternatives has arrived. 